\title{
Regional-scale Predictions of Agricultural N Losses in an Area with a High Livestock Density
}

\author{
Dario Sacco*, Laura Zavattaro, Carlo Grignani \\ Dipartimento di Agronomia, Sevicoltura e Gestione del Territorio, Università di Torino \\ Via L. Da Vinci 44, 10095 Grugliasco (To), Italy
}

\begin{abstract}
The quantification of the $\mathrm{N}$ losses in territories characterised by intensive animal stocking is of primary importance. The development of simulation models coupled to a GIS, or of simple environmental indicators, is strategic to suggest the best specific management practices. The aims of this work were: a) to couple a GIS to a simulation model in order to predict $\mathrm{N}$ losses; b) to estimate leaching and gaseous $\mathrm{N}$ losses from a territory with intensive livestock farming; c) to derive a simplified empirical metamodel from the model output that could be used to rank the relative importance of the variables which influence $\mathrm{N}$ losses and to extend the results to homogeneous situations. The work was carried out in a 7773 ha area in the Western Po plain in Italy. This area was chosen because it is characterised by intensive animal husbandry and might soon be included in the nitrate vulnerable zones. The high $\mathrm{N}$ load, the shallow water table and the coarse type of sub-soil sediments contribute to the vulnerability to $\mathrm{N}$ leaching. A CropSyst simulation model was coupled to a GIS, to account for the soil surface $\mathrm{N}$ budget. A linear multiple regression approach was used to describe the influence of a series of independent variables on the $\mathrm{N}$ leaching, the $\mathrm{N}$ gaseous losses (including volatilisation and denitrification) and on the sum of the two. Despite the fact that the available GIS was very detailed, a great deal of information necessary to run the model was lacking. Further soil measurements concerning soil hydrology, soil nitrate content and water table depth proved very valuable to integrate the data contained in the GIS in order to produce reliable input for the model. The results showed that the soils influence both the quantity and the pathways of the $\mathrm{N}$ losses to a great extent. The ratio between the $\mathrm{N}$ losses and the $\mathrm{N}$ supplied varied between 20 and $38 \%$. The metamodel shows that manure input always played the most important role in determining the $\mathrm{N}$ losses. Other important factors in draining soils were mineral fertilisation and potential drainage, which played a minor role in poorly draining soils. The drainage of the soil and the water table depth also played an important role by influencing the soil water content and $\mathrm{N}$ losses. The differences among the crops resulted to be very important and it was impossible to produce any indicator to predict $\mathrm{N}$ losses for all the crops together. Estimations of total losses are more reliable than estimations of leaching alone. Estimations of total $\mathrm{N}$ losses for maize and meadows are more reliable than for winter cereals.
\end{abstract}

Key-words: $\mathrm{N}$ losses, CropSyst, dynamic simulation model, GIS, metamodel, animal manure.

\section{Introduction}

In the last two decades, the quantification of $\mathrm{N}$ fluxes at a territorial scale has become a key issue in planning good agricultural practices.

The Nitrate Directive (EEC, 1991) and its regional applications (e.g. Regione Piemonte, 2002) require the implementation of measures to reduce nitrate leaching in water bodies. The regional Rural Development Plan (EEC, 1999) encourage the use of agricultural practices that reduce water pollution and enhance soil quality. Finally, the Water Framework Directive, which has recently been adopted in Italy (2006) specifies future objectives to increase the quality not only of deep water, but also of surface water.

Attention towards $\mathrm{N}$ gaseous emission has also increased since the Kyoto Protocol on greenhouse gas emission was adopted in 1997.

Environmental regulations can only be efficiently implemented if they are supported by tools that are able to quantify $\mathrm{N}$ fluxes and to evaluate alternative scenarios that could be proposed as solutions for the reduction of $\mathrm{N}$ losses.

Several experimental trials, aimed at assessing the impact of fertilization management practices on the soil and water quality, have been 
carried out throughout Europe in recent years (e.g. Webb et al., 2000; Eltun et al., 2002; Schröder et al., 2003; Öborn et al., 2003; Karlsson et al., 2003; Giardini, 2004; Nevens and Reheul, 2005; Thomsen, 2005).

Processes involved in soil-plant system management are complex and are influenced by several environmental factors. Field experiments do not directly supply all the information necessary to manage $\mathrm{N}$ efficiently in all environments.

Simulation models are very powerful tools to analyze complex systems, to extend field experimental results and to evaluate alternative scenarios. After their calibration and evaluation in known situations, they help to quantify $\mathrm{N}$ losses both in real situations and in generated scenarios. Some applications aimed at quantifying the fluxes at a field scale can be found in Morari and Giupponi (1997), Donatelli et al. (1997), Grignani and Zavattaro (2000).

When the application is addressed to a large area, the reliability of the simulation results is closely dependent on the availability and the quality of the model input dataset.

This type of application can be carried out by coupling a simulation model and a database (or a GIS) that describe a territory (e.g. Morari et al., 2004); alternatively, indicators can be used with the aim of ranking different situations or scenarios.

Some indicators have been developed to evaluate the capability of the soil to receive manure or to protect deep water from $\mathrm{N}$ pollution. Most of them are mainly driven by the characteristics of the soil (ERSAL, 1992; Giardini and Giupponi, 1993; Regione Emilia Romagna, 1993), while others mainly take into account average agricultural practices (Padovani and Trevisan, 2002).

The problem of manure management is quite important in territories with intensive livestock farming where manure is considered a waste rather than a fertiliser.

The aims of this work are:

1) to couple a GIS that provides a large set of information at the cadastral parcel scale to a simulation model in order to predict $\mathrm{N}$ losses;

2) to estimate leaching and gaseous $\mathrm{N}$ losses from a territory with intensive livestock farming using the GIS + the developed model tool;
3) to derive a simplified empirical metamodel from the model output that could be used to rank the relative importance of the variables which influence $\mathrm{N}$ losses and to extend the results to homogeneous situations.

\section{Materials and methods}

\subsection{The area}

The work was carried out in a 7773 ha area in the Western Po plain (Piedmont, Italy) (Sacco et al., 2003a). This area was chosen because it is characterised by intensive animal husbandry and might soon be included in the nitrate vulnerable zones (EEC, 1991). The high $\mathrm{N}$ load, the shallow water table and the coarse type of sub-soil sediments contribute to the vulnerability to $\mathrm{N}$ leaching.

The sum of arable land and grassland represents $69 \%$ of the total area. The main crop is maize (Zea mays L.) followed by grassland (mainly permanent meadows with Lolium multiflorum L., L. perenne L. and Trifolium repens L.). Other important crops are wheat (Triticum aestivum L.), barley (Hordeum vulgare L.), soybean (Glycine max L.) and fruit trees.

The average animal stocking rate varies between $2.63 \mathrm{t} \mathrm{ha}^{-1}$ live weight in cattle farms and $4.27 \mathrm{t} \mathrm{ha}^{-1}$ in pig farms. An important reduction in manure- $\mathrm{N}$ load in intensive farms is obtaine through exporting liquid manure to other farms.

\subsection{The GIS}

The Geographical Information System (GIS) presented by Sacco et al. (2003a) was the main source of information used as input to simulate the $\mathrm{N}$ cycle at a territorial scale (Table 1 ).

The GIS was built with the aim of supporting the spatial calculation of the soil surface budget (Aarts et al., 2000) for nitrogen, phosphorous and potassium, and was further expanded with the purpose of providing inputs to a dynamic cropping system simulation model. This paper only refers to nitrogen.

The soil surface budget was calculated as the difference between all the fertilisation inputs and crop removal.

Information was derived for each cadastral parcel that represents a unit of information of the digital maps used in the GIS. The cadastral parcel allows the digital cadastral map to be related to Italian administrative databases. The 
Table 1. Information derived from the GIS (Sacco et al., 2003a) and used to produce the input of the simulation model.

\begin{tabular}{lll}
\hline Information & Source & Reference period \\
\hline Type of crop & CAP database & $1996-1998$ \\
Mineral fertilisation & Local experts & average 1996-2000 \\
Liquid manure use & Provincial official database & 2000 \\
Farm animal stocking rate & Animal livestock register & 2000 \\
\hline
\end{tabular}

GIS includes information on $\mathrm{N}$ management, soils and water tables.

\subsection{Nitrogen management}

The mineral fertilisation was described for each crop. Separate estimates were made for livestock farms and non-livestock farms with the aid of a group of local experts.

The list of cadastral parcels that receive liquid manure and the farms producing this manure were derived from the Provincial official database which lists all liquid manure distributions.

The total amount of nitrogen in the form of solid or liquid manure applied to each parcel was derived from the regional animal livestock register on the basis of the quantity of excreted $\mathrm{N}$ from each animal category (Sacco et al., 2003a).

\subsection{The soils}

Seven main soil types were identified according to the Local Soil Survey Service (IPLA, 2006), according to the Soil Taxonomy of Soil Conser- vation Service of USDA assessment (USDA, 1977). The main soil characteristics are described in table 2.

The ACGH, COL and SAGN soils were characterised by a high stone content in the profile. AQPR was also characterised by a high stone content in the profile below one meter. BONV and CUSS were characterised by evident signs of reduction along the profile during most of the year. CENT was a very deep soil with low permeability.

A soil type was assigned to each cadastral parcel according to the Regional Soil Map. Seven benchmark profiles, one for each of the seven soil types, were characterised in detail by Sacco (2000), measuring the hydrological and chemical characteristics of each horizon and monitoring the matric potential and the $\mathrm{N}$ concentration along the profile for two years.

\subsection{The water table}

The water table in the area is quite shallow, ranging from 13 meters to almost the soil surface.

Table 2. Average characteristics of the soils used in the simulations. The minimum and the maximum values measured in the different horizons of the profile are reported in brackets.

\begin{tabular}{|c|c|c|c|c|c|c|}
\hline Soil & Series & $\begin{array}{l}\text { USDA Soil } \\
\text { Taxonomy }\end{array}$ & Texture & Bulk density & $\begin{array}{l}\text { Stone } \\
\text { content }\end{array}$ & $\begin{array}{c}\text { Saturated } \\
\text { hydraulic } \\
\text { conductivity }\end{array}$ \\
\hline & & & & $\mathrm{kg} \mathrm{m}^{-3}$ & $\%$ & $\mathrm{~m} \mathrm{~d}^{-1}$ \\
\hline ACGH & $\begin{array}{c}\text { Acquasana } \\
\text { ghiaiosa }\end{array}$ & Aquic Haplustept & Sandy loam & $1540^{\mathrm{a}}$ & $\begin{array}{c}45 \\
(2-80)\end{array}$ & $\begin{array}{c}0.260 \\
(0.093-0.945)\end{array}$ \\
\hline AQPR & $\begin{array}{l}\text { Acquasana } \\
\text { profonda }\end{array}$ & Aquic Haplustept & Loam & $\begin{array}{c}1632 \\
(1510-1720)\end{array}$ & $\begin{array}{c}20 \\
(2-70)\end{array}$ & $\begin{array}{c}0.320 \\
(0.094-1.974)\end{array}$ \\
\hline BONV & $\begin{array}{c}\text { Bonavia } \\
\text { tipica }\end{array}$ & Aeric Endoaquept & Silty loam & $\begin{array}{c}1587 \\
(1420-1760)\end{array}$ & $\begin{array}{c}1 \\
(0-15)\end{array}$ & $\begin{array}{c}0.064 \\
(0.034-0.896)\end{array}$ \\
\hline CENT & $\begin{array}{c}\text { Centallo } \\
\text { tipica }\end{array}$ & Dystric-Fluventic Eutrudept & Sandy loam & $\begin{array}{c}1277 \\
(1210-1490)\end{array}$ & $\begin{array}{c}0 \\
(0-3)\end{array}$ & $\begin{array}{c}0.251 \\
(0.109-1.335)\end{array}$ \\
\hline $\mathrm{COL}$ & $\begin{array}{l}\text { Colombero } \\
\text { tipica }\end{array}$ & Tipic Haplustalf & Loamy sand & $\begin{array}{c}1457 \\
(1360-1545)\end{array}$ & $\begin{array}{c}39 \\
(20-50)\end{array}$ & $\begin{array}{c}0.480 \\
(0.459-5.346)\end{array}$ \\
\hline CUSS & $\begin{array}{c}\text { Cussanio } \\
\text { tipica }\end{array}$ & Typic Endoaquoll & Sandy loam & $\begin{array}{c}1495 \\
(1330-1660)\end{array}$ & $\begin{array}{c}4 \\
(0-25)\end{array}$ & $\begin{array}{c}0.141 \\
(0.043-7.425)\end{array}$ \\
\hline SAGN & $\begin{array}{l}\text { Sagnassi } \\
\text { tipica }\end{array}$ & Fluventic Hapludoll & Silty loam & $\begin{array}{c}1416 \\
(1270-1720)\end{array}$ & $\begin{array}{c}34 \\
(5-60)\end{array}$ & $\begin{array}{c}0.158 \\
(0.088-0.408)\end{array}$ \\
\hline
\end{tabular}

${ }^{\mathrm{a} B u l k}$ density was measured in only one horizon. 
The water table depth was derived by interpolating the average measurements from 16 wells in the area during 1999-2000 period. Interpolation was performed using a Triangular Irregular Network procedure and a $50 \times 50 \mathrm{~m}^{2}$ grid size. An average depth was then calculated for each cadastral parcel. Temporal variability of the water table depth was not considered.

\subsection{The simulation model}

The simulation model chosen was CropSyst 3.04.08 because of its capability to study the effects of climate, soils, and management on cropping system productivity and the environment (Stöckle et al., 2003), and also because it has already been tested in similar environments (e.g. Donatelli et al., 1997; Bechini et al., 2003; Morari et al., 2004). Its ability to simulate cropping systems in situations where the water table is particularly shallow has been demonstrated by Sacco et al. (2001).

\subsection{Model parameterisation}

The climate was considered homogeneous throughout the area because of its limited extension. Rainfall and temperature data were provided by the Technical School of Agriculture "ITAS Barbero" in Fossano (CN). Solar radiation was provided by the Piedmont Regional Environmental Agency (ARPA). The meteorological stations were both situated inside the area. The period covered by the complete dataset was 12 years.

The hydrological and chemical parameters used in the simulations for each cadastral parcel were considered equal to those described for each reference soil profile according to the assignment performed through GIS elaboration.

In order to reduce the number of simulations, the water table depth was not considered a continuous variable over the area, but it was discretised into nine different classes. Figure 1 reports the average water table depth for each soil type. CropSyst does not take the water table into account when it is deeper than $5 \mathrm{~m}$ : in this case, it simulates free drainage.

The parameters that describe the $\mathrm{N}$ cycle in the model were derived from a calibration on nitrate and ammonium concentrations periodically measured in the field by Sacco (2000). The mineralization rate adjustment, nitrification rate adjustment and denitrification rate adjustment

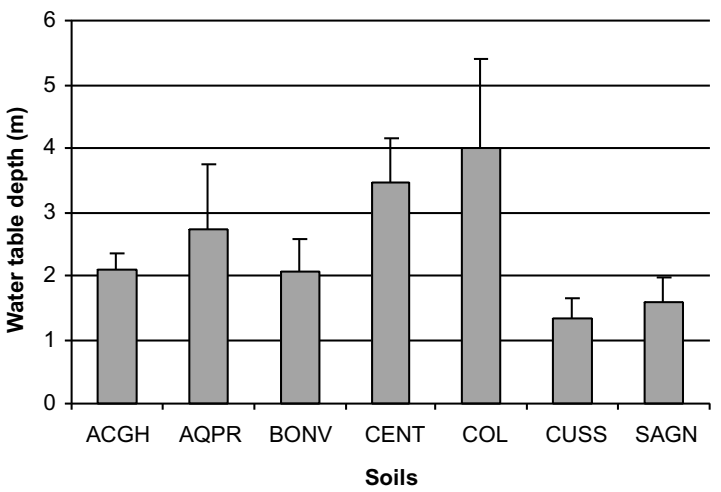

Figure 1. Average water table depth for the different soil types (source: GIS). The error bars represent one standard deviation of the variability between the cadastral parcels.

values used in the simulations were 0.05 . The maximum depth at which organic matter turnover occurs was $0.5 \mathrm{~m}$ in BONV, 0.6 in ACGH, COL, CUSS and SAGN and 0.8 in AQPR and in CENT.

The crop rotations were derived considering cultivated crops in each parcel in the 1996-1998 period (CAP database).

The less common crops in the area were not considered in order to reduce the number of simulations: only maize, wheat, barley, meadows, soybean and set aside were analysed. The sum of their area covered more than $90 \%$ of the area described by the GIS. The remaining $10 \%$ was excluded from the simulation. In order to evaluate the effects of weather variability, the threeyear rotation was replicated in each parcel four times to build a 12-year series, which is the period covered by the available weather dataset.

Table 3 reports the percentage area of the different crops that were simulated on the soil types. The coefficient of variation $(\mathrm{CV})$ shows the variability over the three years. Meadows are more diffused on soils with shallower water tables. The coefficient of variation was small in most of the soils, showing a stability of the crop ratio over the years even though the crops were rotated over the different fields.

The parameterisation of the different crops was derived from a previous work (Monaco et al., 2002) in a similar environment (Table 4).

As conventional tillage is the most diffused agricultural practice in this area, a ploughing and a rotary tiller operation was systematically simulated before sowing for all the crops.

Irrigation was very different for the various 
Table 3. Percent of area covered by the different crops simulated over the soils. The coefficient of variation refers to the annual variability during the 1996-1998 period.

\begin{tabular}{|c|c|c|c|c|c|c|c|}
\hline Soil & & Maize & Wheat & Barley & Meadows & Set aside & Soybean \\
\hline \multirow[t]{2}{*}{ ACGH } & Average & 49 & 21 & 5 & 23 & 2 & 0 \\
\hline & CV & 6 & 22 & 27 & 5 & 0 & 0 \\
\hline \multirow[t]{2}{*}{ AQPR } & Average & 61 & 15 & 8 & 15 & 1 & 1 \\
\hline & $\mathrm{CV}$ & 0 & 3 & 5 & 1 & 7 & 17 \\
\hline \multirow[t]{2}{*}{ BONV } & Average & 47 & 19 & 7 & 25 & 1 & 2 \\
\hline & $\mathrm{CV}$ & 3 & 8 & 7 & 3 & 10 & 29 \\
\hline \multirow[t]{2}{*}{ CENT } & Average & 60 & 8 & 7 & 23 & 0 & 0 \\
\hline & $\mathrm{CV}$ & 2 & 9 & 10 & 3 & 8 & 0 \\
\hline \multirow[t]{2}{*}{ COL } & Average & 56 & 8 & 15 & 18 & 0 & 3 \\
\hline & $\mathrm{CV}$ & 1 & 3 & 3 & 2 & 7 & 23 \\
\hline \multirow[t]{2}{*}{ CUSS } & Average & 46 & 13 & 3 & 34 & 2 & 2 \\
\hline & $\mathrm{CV}$ & 2 & 6 & 11 & 1 & 13 & 22 \\
\hline \multirow[t]{2}{*}{ SAGN } & Average & 51 & 14 & 6 & 26 & 1 & 3 \\
\hline & $\mathrm{CV}$ & 1 & 6 & 4 & 3 & 36 & 29 \\
\hline \multirow[t]{2}{*}{ Total } & Average & 54 & 13 & 9 & 22 & 1 & 2 \\
\hline & $\mathrm{CV}$ & 4 & 3 & 6 & 3 & 4 & 6 \\
\hline
\end{tabular}

Table 4. Crop parameters used for the simulations.

\begin{tabular}{lcccccc}
\hline Parameter & Maize & Maize & Wheat & Barley & Meadows* & Soybean \\
\hline Above ground biomass transpiration coefficient & 10.0 & 10.0 & 5.0 & 4.5 & 5.0 & 4.5 \\
Light to above ground biomass conversion & 3.5 & 3.5 & 3.0 & 3.0 & 3.0 & 3.0 \\
Specific leaf area & 23 & 23 & 22 & 22 & 26 & 28 \\
Stem / leaf partition coefficient & 2.5 & 2.5 & 4.0 & 4.0 & 1.7 & 3.0 \\
Extinction coefficient for solar radiation & 0.50 & 0.50 & 0.48 & 0.48 & 0.48 & 0.48 \\
N fixation & no & no & no & no & yes & yes \\
Maximum N concentration during early growth & 0.038 & 0.038 & 0.030 & 0.030 & 0.060 & 0.060 \\
Maximum N concentration at maturity & 0.012 & 0.012 & 0.015 & 0.015 & 0.026 & 0.050 \\
Maximum N concentration at maturity & 0.007 & 0.007 & 0.011 & 0.011 & 0.012 & 0.010 \\
Maximum N content of standing stubble & 0.006 & 0.006 & 0.007 & 0.007 & 0.012 & 0.010 \\
\hline
\end{tabular}

"The meadows were mainly permanent. Lolium multiflorum L., L. perenne L. and Trifolium repens L. characterise the most common facies.

soil types. The number of irrigations was derived from interviews with local experts and is reported in table 5. Each irrigation was considered to supply the crop with about $75 \mathrm{~mm}$ of water, an average value for this area where surface irrigation is mainly used. Winter cereals never received irrigations.

The parameterisation of the liquid manure differs from that of the solid manure. The percentage of ammonium is $50 \%$ in liquid manure and $10 \%$ in solid manure (Regione Emilia Romagna, 1993). The decomposition time constant, which represents the time during which, in standard conditions, $63 \%$ of the $\mathrm{N}$ contained in the added organic material is released, was set to 100 and 240 days for liquid and solid manure, respectively, after calibration in benchmark situations (Sacco, 2000).
Table 5. Number of irrigations of $75 \mathrm{~mm}$ each supplied each year to the crops (source: interviews with local experts).

\begin{tabular}{lccc}
\hline Soil & Maize & Meadows & Soybean \\
\hline ACGH & 5 & 5 & - \\
AQPR & 3 & 3 & 3 \\
BONV & 3 & 3 & 3 \\
CENT & 3 & 3 & 3 \\
COL & 5 & 5 & 5 \\
CUSS & 2 & 2 & 2 \\
SAGN & 5 & 5 & 5 \\
\hline
\end{tabular}

The ammonia volatilisation losses closely depend on the characteristics of the soil, on the type of fertiliser, on the weather and on the practices adopted by the farmer to spread the fertiliser (Sommer and Hutchings, 2001). As no direct information was available concerning this, ammonia losses were set equal to $10 \%$ of am- 
Sacco D., Zavattaro L., Grignani C.

Table 6. Percent of area treated with different types of fertiliser over the soils (source: GIS).

\begin{tabular}{|c|c|c|c|c|c|c|}
\hline Soil type & $\begin{array}{l}\text { Solid manure } \\
+ \text { mineral }\end{array}$ & $\begin{array}{l}\text { Liquid manure } \\
+ \text { mineral }\end{array}$ & $\begin{array}{l}\text { Both organic } \\
+ \text { mineral }\end{array}$ & $\begin{array}{l}\text { Total organic } \\
+ \text { mineral }\end{array}$ & Only mineral & Total \\
\hline $\mathrm{ACGH}$ & 46 & 17 & 6 & 69 & 31 & 100 \\
\hline AQPR & 34 & 33 & 9 & 76 & 24 & 100 \\
\hline BONV & 33 & 32 & 8 & 73 & 27 & 100 \\
\hline CENT & 25 & 41 & 12 & 78 & 22 & 100 \\
\hline COL & 28 & 30 & 7 & 65 & 35 & 100 \\
\hline CUSS & 21 & 33 & 3 & 57 & 43 & 100 \\
\hline SAGN & 27 & 34 & 8 & 69 & 31 & 100 \\
\hline Total & 29 & 32 & 7 & 69 & 31 & 100 \\
\hline
\end{tabular}

Table 7. Total amount of $\mathrm{N}$ applied with different fertilisation strategies (source: GIS). CV refers the variability among parcels belonging to the same soil. Values are in $\mathrm{kg} \mathrm{N} \mathrm{ha}^{-1} \mathrm{y}^{-1}$. Av. = average. $\mathrm{CV}=$ Coefficient of variation.

\begin{tabular}{lcccccccccc}
\hline Soil & \multicolumn{2}{c}{$\begin{array}{c}\text { Solid manure } \\
+ \text { mineral }\end{array}$} & \multicolumn{2}{c}{$\begin{array}{c}\text { Liquid manure } \\
+ \text { mineral }\end{array}$} & \multicolumn{2}{c}{$\begin{array}{c}\text { Both manure } \\
+ \text { mineral }\end{array}$} & \multicolumn{2}{c}{ Only mineral } & & Average \\
\hline ACGH & 97 & 27 & 311 & 21 & 146 & 53 & 180 & 36 & 152 & 57 \\
AQPR & 111 & 39 & 246 & 49 & 128 & 34 & 153 & 39 & 161 & 57 \\
BONV & 96 & 39 & 226 & 40 & 105 & 40 & 125 & 53 & 145 & 59 \\
CENT & 124 & 29 & 291 & 47 & 156 & 19 & 163 & 36 & 202 & 59 \\
COL & 109 & 45 & 209 & 39 & 120 & 38 & 139 & 46 & 149 & 51 \\
CUSS & 95 & 41 & 234 & 29 & 156 & 0 & 121 & 63 & 145 & 60 \\
SAGN & 88 & 41 & 268 & 44 & 112 & 27 & 136 & 45 & 158 & 66 \\
\hline Total & 105 & 42 & 235 & 44 & 124 & 35 & 138 & 48 & 155 & 58 \\
\hline
\end{tabular}

monium- $\mathrm{N}$ for all fertiliser types according to Sommer and Hutchings (2001). This is a reasonably low value, supposing that a good fertiliser management is applied.

Table 6 reports the different types of fertilisers used over the area. Thirty one percent of the area received only mineral fertilisation. The area receiving manure fertilisation was split into almost two equal parts between liquid and solid manure, with small differences for the different soil types. A small part of the area received both solid and liquid manure on the same crop and in the same year. Table 7 shows the average amounts of $\mathrm{N}$ applied according to the type of fertilisation. The lowest values refer to the solid manure while the highest values refer to the liquid manure. The soil showing the highest average values is CENT where the fertilisation rate was $202 \mathrm{~kg} \mathrm{~N} \mathrm{ha}^{-1} \mathrm{y}^{-1}$; all the others ranged between 145 and $161 \mathrm{~kg} \mathrm{~N} \mathrm{ha}^{-1} \mathrm{y}^{-1}$.

The number of simulations for each type of soil is reported in table 8 .

\subsection{Metamodels for estimating $N$ losses}

A linear multiple regression approach was used to describe the influence of a series of inde- pendent variables on the $\mathrm{N}$ leaching, the $\mathrm{N}$ gaseous losses (including volatilisation and denitrification) and on the sum of the two.

Independent variables were liquid manure, solid manure, mineral fertiliser, potential drainage, water table depth, stone content, bulk density and saturated hydraulic conductivity.

The potential drainage was estimated for each parcel and for each year through the following equation:

\section{Potential drainage $=$ Rainfall + Irrigation - Potential Evapotranspiration}

Table 8 . Area covered by each type of soil and including the number of simulations reported. The number of simulations corresponds to the number of cadastral parcels.

\begin{tabular}{lcc}
\hline Soil & Area (ha) & Number of simulations \\
\hline ACGH & 37 & 37 \\
AQPR & 1054 & 891 \\
BONV & 774 & 610 \\
CENT & 293 & 302 \\
COL & 1536 & 1686 \\
CUSS & 597 & 549 \\
SAGN & 500 & 459 \\
\hline TOTAL & 4794 & 4534
\end{tabular}




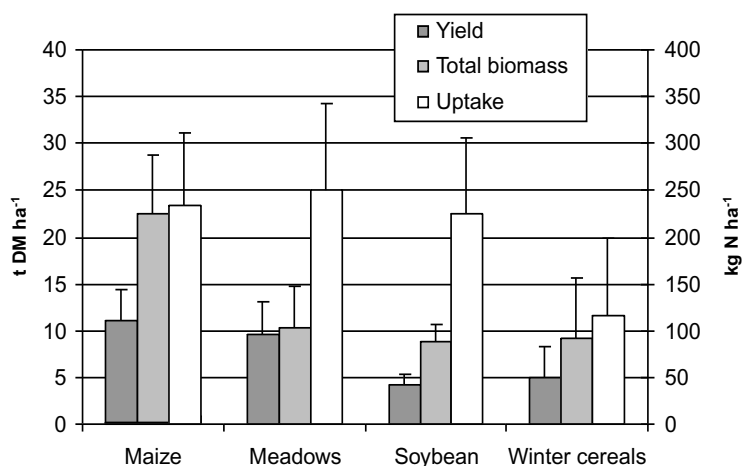

Figure 2. Simulated yield, total above ground biomass and above ground nitrogen uptake for the different crops. The error bars represent one standard deviation between the cadastral parcels (including soils) and years.

The linear multiple regression was performed using a stepwise method with stepping method criteria based on the probability of $F$. A probability of 0.05 was selected to include the variable in the model, while a probability of 0.10 was used to exclude it.

The software used in this analysis was the SPSS Release 13.0.

The model results from the ACGH soil were not subject to multiple linear regression because of the small number of cases in comparison with the other soils.

\section{Results and discussion}

\subsection{Crop production and crop uptake}

Figure 2 reports the average crop yield, total biomass and $\mathrm{N}$ uptake for each crop. The simulated values of grain production and total biomass appear close to results of experiments run in the same region (Sacco et al., 2003b; Monaco, 2006). The predicted $\mathrm{N}$ concentrations of the different crops (data not shown) were close to those published in Grignani et al. (2003).

Figure 3 reports the results of crop $\mathrm{N}$ uptake for different soils: the differences are a consequence of the different crop ratios and of the effect of soil type on the crop uptake.

The variability resulted to be quite high. CENT was the soil with the highest average uptake; this is partially due to the high proportion of maize and to the low percentage of set aside. ACGH was the soil with the lowest crop $\mathrm{N}$ uptake. This is caused by a high percentage of win-

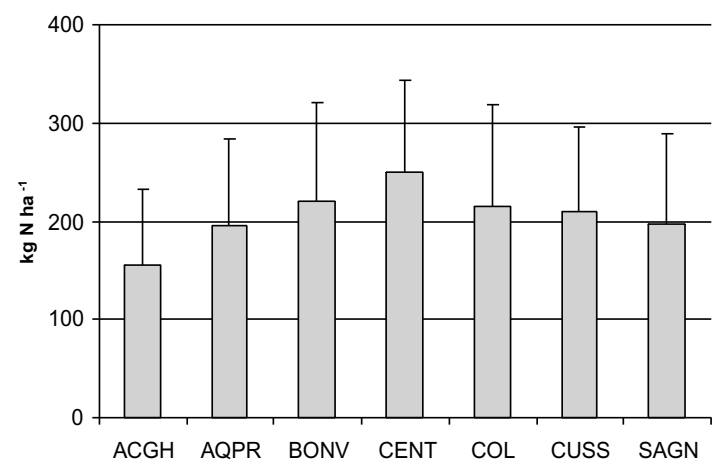

Figure 3. Simulated nitrogen uptake for the different soils. The error bars represent one standard deviation of the variability between the cadastral parcels and years.

ter cereals and by their lower $\mathrm{N}$ uptake due to high drainage, which is detrimental, especially for non-irrigated crops.

\subsection{Nitrogen losses}

Figure 4 describes the average values of water drainage. In BONV, the upward fluxes of water prevailed: the low hydraulic conductivity of some horizons reduced the infiltration of water from the top and the shallow water table favoured the supply of water from the bottom. The downward fluxes prevailed in all the other soils and drainage values ranged from 100 to $423 \mathrm{~mm}$ per year. No simple relationships exist between the water table depth and the amount of drainage. This probably depends on the hydrological characteristics of the different horizons of the soil and also on their succession.

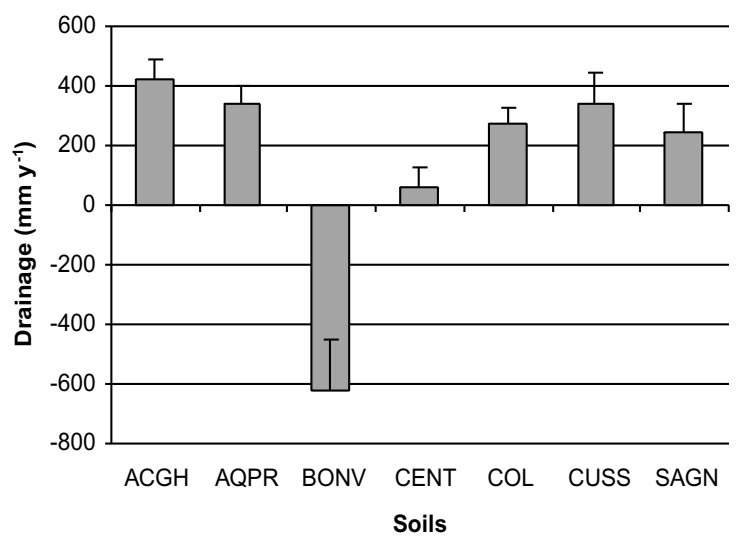

Figure 4. Simulated average water drainage from the different soils. The error bars represent one standard deviation of the variability between the cadastral parcels and years. 


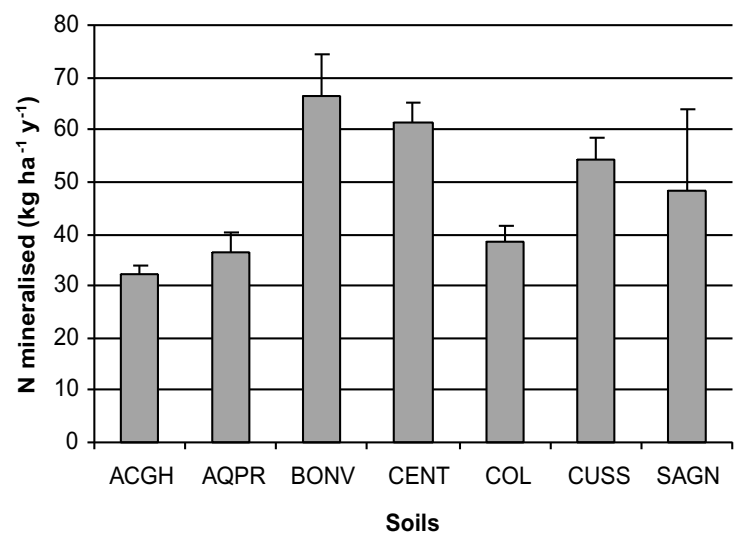

Figure 5. Simulated average $\mathrm{N}$ mineralization of stable soil organic matter of the different soils. The error bars represent one standard deviation of the variability between the cadastral parcels and years.

Nitrogen mineralization represents the natural supply of mineral $\mathrm{N}$ to the soil profile (Fig. 5). The average values ranged from $32 \mathrm{~kg} \mathrm{ha}^{-1}$ $\mathrm{y}^{-1}$ in ACGH to about $66 \mathrm{~kg} \mathrm{ha}^{-1} \mathrm{y}^{-1}$ in BONV. The higher values were estimated in BONV and CENT, the two soils with minimum drainage, followed by CUSS and SAGN, those with the shallowest water table. These four soils were the four types with the highest water content. Minimum values of $\mathrm{N}$ mineralization were simulated in ACGH and AQPR, the soils showing the maximum drainage and the lowest water content.

Nitrogen leached values are reported in figure 6 . The two soils with the minimum drainage (BONV and CENT) showed the minimum $\mathrm{N}$

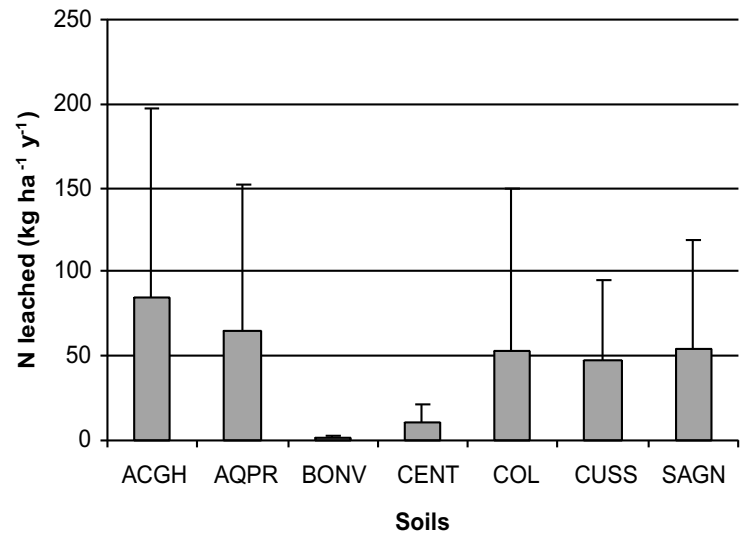

Figure 6. Simulated average $\mathrm{N}$ leached from the different soils. The error bars represent one standard deviation of the variability between the cadastral parcels and years. leaching and the two soils with the maximum drainage (ACGH and AQPR) showed the maximum leaching of $\mathrm{N}$. The values ranged between ca. $0 \mathrm{~kg} \mathrm{~N}^{-1} \mathrm{y}^{-1}$ in BONV and $85 \mathrm{~kg} \mathrm{~N}^{-1}$ $\mathrm{y}^{-1}$ in $\mathrm{ACGH}$; the standard deviation was greater than $200 \mathrm{~kg} \mathrm{~N} \mathrm{ha}^{-1} \mathrm{y}^{-1}$ in some soils. The $\mathrm{N}$ leached values are close to those predicted by Grignani and Zavattaro (2000) in the same environment.

Figure 7 represents the values of the average annual $\mathrm{N}$ concentration of the water drainage. The average annual values ranged between 0 and $26 \mathrm{mg} \mathrm{N}^{-1}$. Only BONV and CENT were under the limit of $11.3 \mathrm{mg} \mathrm{N}^{-N_{3}}{ }^{-1}{ }^{-1}$ (EEC, 1991) while all the other soils exceeded this limit, contributing to the increase in the $\mathrm{N}$ concentration in the water table.

Figure 8 shows the $\mathrm{N}$ denitrification and the total gaseous losses in the different soils.

Denitrification ranged between 0 and $88 \mathrm{~kg}$ $\mathrm{N}$ ha $^{-1} \mathrm{y}^{-1}$. Denitrification was low, as expected, in the soils characterised by a fast draining regime (0.4-10 $\left.\mathrm{kg} \mathrm{N} \mathrm{ha}^{-1} \mathrm{y}^{-1}\right)$. Arcara et al. (1999) provide one of the few experimental pieces of evidence in Italy that confirm these predictions.

The higher denitrification values were predicted in BONV, CENT and SAGN (44-88 kg $\mathrm{N}$ ha $^{-1} \mathrm{y}^{-1}$ ), the soils characterised by a high moisture content. These estimates are not far from the 40-75 $\mathrm{kg} \mathrm{N} \mathrm{ha}^{-1} \mathrm{y}^{-1}$ denitrification values estimated with the $\mathrm{N}$ balance method by Hofstra and Bouwman (2005) in relation to upland crops cultivated in poorly drained soils and fertilised with 75-300 $\mathrm{kg} \mathrm{N}^{-1} \mathrm{y}^{-1}$.

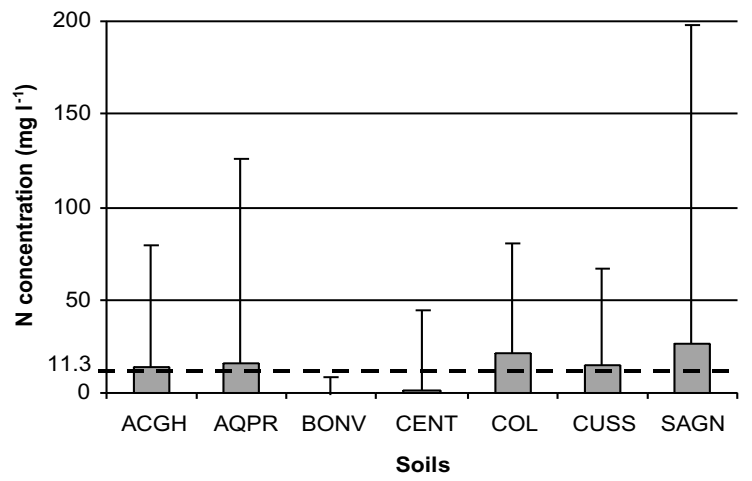

Figure 7. Simulated average concentration of $\mathrm{N}^{-\mathrm{NO}_{3}}{ }^{-}$in the water drained from the different soils. The dotted line corresponds to the limit of $11.3 \mathrm{mg} \mathrm{N}-\mathrm{NO}_{3} \mathrm{l}^{-1}$ of the Nitrate Directive. The error bars represent one standard deviation of the variability between the cadastral parcels and years. 


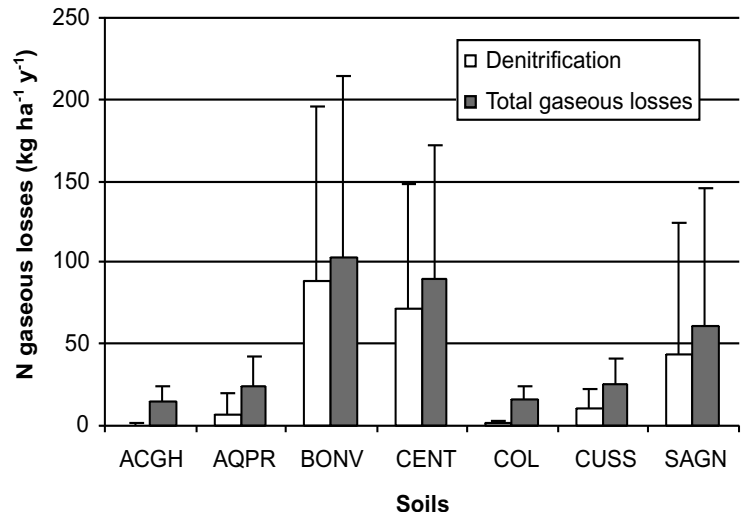

Figure 8. Simulated average $\mathrm{N}$ gaseous losses from the different soils. The error bars represent one standard deviation of the variability between the cadastral parcels and years.

A model analysis run by Marchetti et al. (1997) suggests that the daily denitrification rates for the Italian environment could be compatible with the data shown in figure 8 .

Ammonia volatilisation was less variable as it only depends on the fertilisation supply.

Figure 9 shows the ratio between the total losses (leaching + gaseous) and the $\mathrm{N}$ fertilisation in the different soils. Values varied between 20\% (CENT) and 38\% (CUSS): the shallower the water table, the higher the ratio. This indicates that, in general, the water table depth is important to determine $\mathrm{N}$ efficiency.

\subsection{Metamodels for estimating $N$ losses}

When the regression analysis was initially performed using all the independent variables, the soil descriptors (bulk density, stone content and saturated hydraulic conductivity) were either excluded from the model or included with a very low contribution to the regression. They were therefore excluded from further regression analyses.

Table 9 reports the relationship between the amount of $\mathrm{N}$ leaching and the amount of fertiliser supplied in different forms, the amount of potential drainage and the depth of the water table.

Regressions for maize and meadows showed better coefficients of determination than for winter cereals. This is probably due to the fact that, during spring and summer, the processes of mineralization from organic matter, residues and overall manures are more regular and they

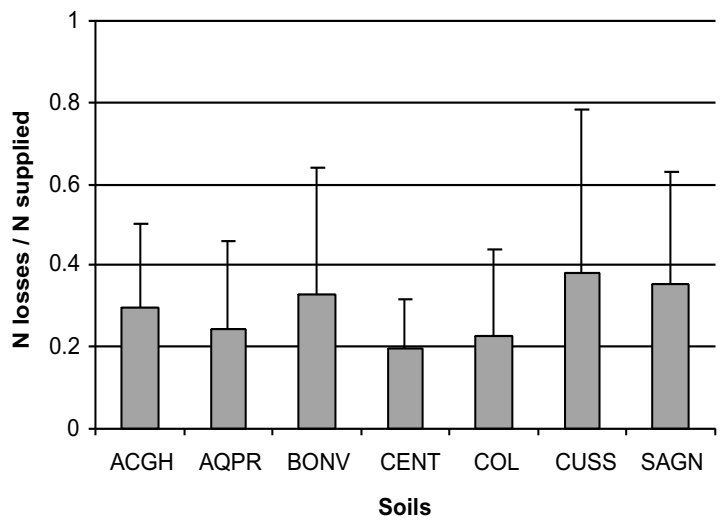

Figure 9. Simulated average ratio of $\mathrm{N}$ losses and fertilisation $\mathrm{N}$ supply to the different soils. The error bars represent one standard deviation of the variability between the cadastral parcels and years.

occur contemporarily to crop growth, while during autumn and winter the processes are more subject to weather variability.

Considering all the soils together, manure fertilisation and the amount of potential drainage were the parameters that influenced $\mathrm{N}$ leaching the most. Mineral fertilisation showed different degree of importance, depending on the crop. The water table depth played a minor role. As expected, the amount of $\mathrm{N}$ leaching increased with the increase in the amount of fertilisation and in potential drainage.

Morari et al. (2004) also demonstrate the importance of the irrigation scenario (and therefore of the potential drainage), on $\mathrm{N}$ leaching, underlining the necessity of introducing this aspect into Environmental legislation. Moreover, considering the results of this metamodel, the role of mineral fertilisation should also be carefully considered in future regulations.

The coefficient related to the water table depth was negative, which means that the shallower the water table, the greater the $\mathrm{N}$ leaching.

Considering the different soils, the coefficients of determinations were higher in AQPR, COL, CUSS and SAGN. These were the soils where the drainage was greater. In these soils, even with some differences arising from the different variables included in the model, the considerations drawn for the main regression including all soil types, are still valid.

CENT and BONV have different behaviour in comparison to the other soils.

In CENT the coefficient of determination 
Sacco D., Zavattaro L., Grignani $C$.

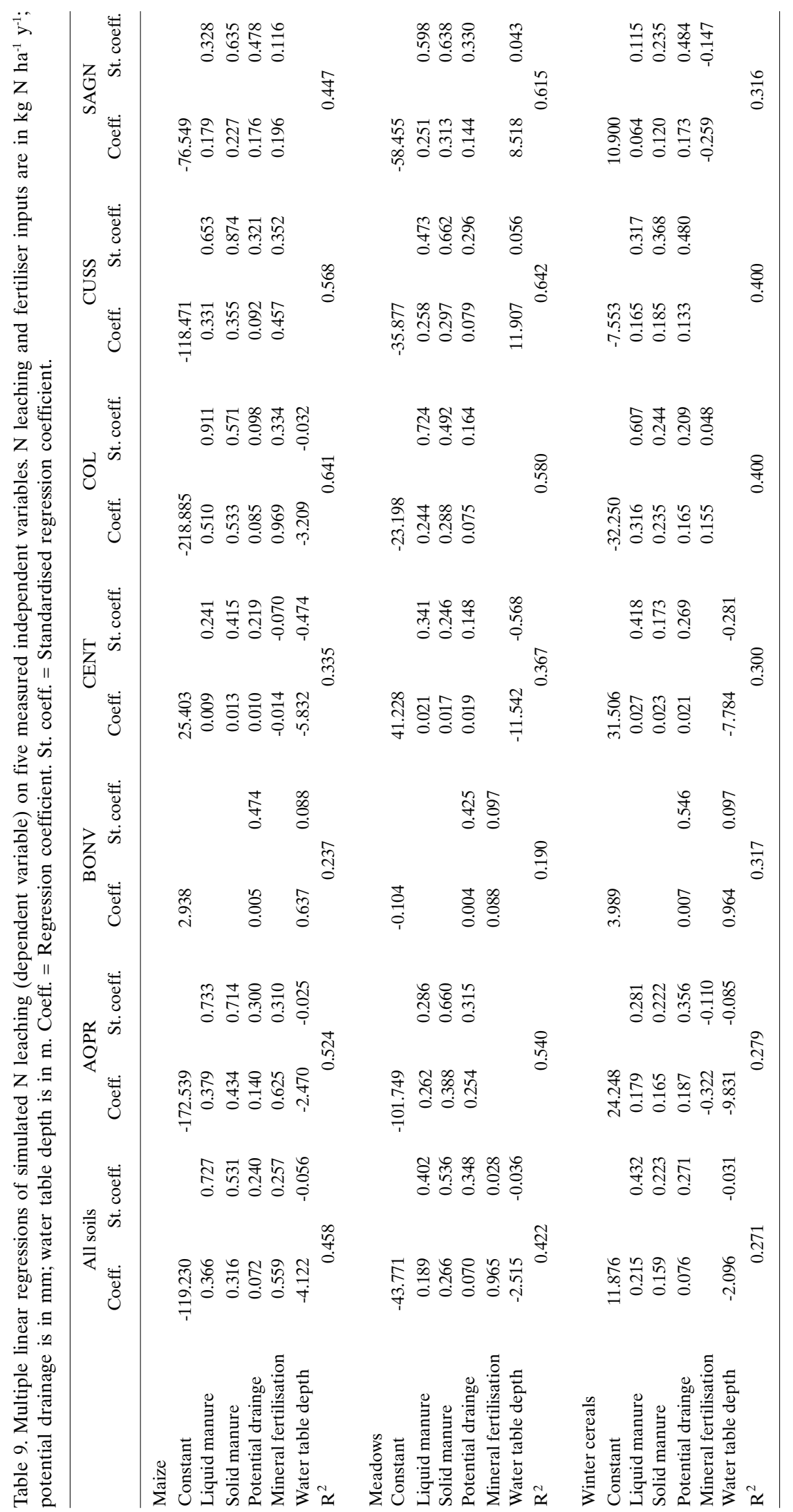




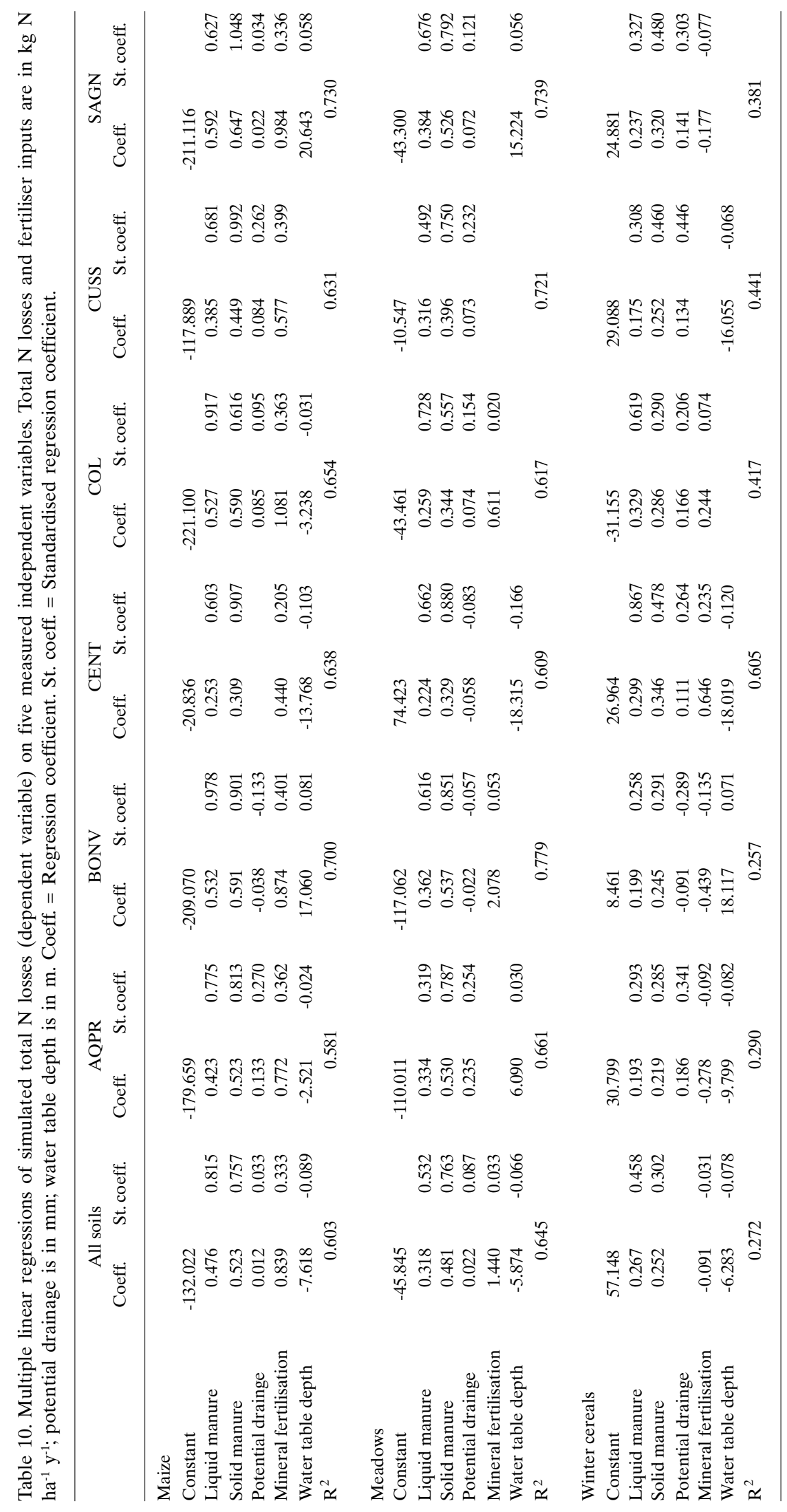


was lower than for all the soils grouped together. The coefficient of the mineral fertilisation was negative, but this is probably only due to the randomness and not to the reverse role of the mineral fertilisation in the regression.

Finally, the relationship in BONV is quite poor. Manure fertilisations never appear in the regression and mineral fertilisation appeared only in meadows. One reason for this could be the strong influence of capillary rise.

Table 10 reports the results of the regression between the total amount of $\mathrm{N}$ losses and the amount of fertiliser supplied in the different forms, the amount of potential drainage and the depth of the water table.

The relationships describing total $\mathrm{N}$ losses showed higher coefficients of determination than those only predicting $\mathrm{N}$ leaching.

As in $\mathrm{N}$ leaching, the relationships in maize and in meadows showed higher coefficients of determination than in winter cereals.

Considering all the soils, the organic fertilisation was the parameter that showed the highest standardized coefficients in all the crops. Mineral fertilisation was important in maize but much less so in meadows or winter cereals. The role of potential drainage was almost completely reduced in respect to the results for $\mathrm{N}$ leaching. Water table depth played a minor role.

As expected, the coefficients of the fertilisations and of the potential drainage were positive in almost all the relationships, meaning that the amount of $\mathrm{N}$ lost increases with an increase in the amount of fertilisation and in the water drained. Mineral fertilisation showed a negative coefficient in winter cereals, but this is probably due to the low coefficient of determination of the relation. The potential drainage in BONV has negative signs for all the crops. The fluxes in this soil are in fact mainly upwards unlike the other soils. Thus, the greater the upward fluxes, the greater the total $\mathrm{N}$ losses. As far as the water table is concerned, the greater its depth, the greater the total $\mathrm{N}$ losses.

When the relationships were split over the different soils, almost all the relationships improved. They only decreased for AQPR maize, CENT and COL meadows and BONV winter cereals.

The most important variables in maize were the manure fertilisers. Mineral fertilisation was always the third parameter in order of impor- tance, while potential drainage and water table depth showed different behaviour for the different soils.

Meadows responded similarly to maize, but the role of the mineral fertilisation was reduced.

Finally, manure fertilisation and potential drainage in winter cereals were the most important variables, while mineral fertilisation and water table depth showed behaviour that changed in relation to the type of soil.

\subsection{Example of an application of the metamodel}

The metamodel described in the previous section, is valuable to compare different situations at a territorial scale in order to provide estimates of $\mathrm{N}$ leaching or total $\mathrm{N}$ losses in specific situations. In this case, if the soil is similar to one of the references, the specific metamodel for the soil can be applied, otherwise, the general relationship is useful.

The metamodel can be applied, for example, to evaluate the effect of two levels of fertilisation on $\mathrm{N}$ losses. An example follows.

In an environment where the average rainfall is $800 \mathrm{~mm}$ per year, maize is irrigated three times per year with a total supply of water of $225 \mathrm{~mm}$. The calculated potential evapotranspiration is equal to $650 \mathrm{~mm}$. Consequently, the potential drainage is equal to $375 \mathrm{~mm}$. The water table is $3 \mathrm{~m}$ deep. Two levels of liquid manure are considered: $170 \mathrm{~kg} \mathrm{~N}^{-1}$ and $340 \mathrm{~kg} \mathrm{~N} \mathrm{ha}^{-1}$, which are the limits of the Nitrate Directive (EEC, 1991) for nitrate vulnerable zones and non vulnerable zone, respectively. The maize also receives $100 \mathrm{~kg} \mathrm{~N} \mathrm{ha}^{-1}$ of mineral fertiliser as top dressing.

Figure 10 reports the results of the application of the metamodels to the described situation in a generic soil and for AQPR, CENT and CUSS.

Considering the generic metamodel for all soils, $\mathrm{N}$ leaching is equal to $13 \mathrm{~kg} \mathrm{~N}^{-1}$ for the lower level of manure input. It increases to 76 $\mathrm{kg} \mathrm{N} \mathrm{ha}^{-1}$ if the higher $\mathrm{N}$ level is considered. The results are similar in the two well draining soils (AQPR and CUSS) with some differences due to the different constant of the model. In CENT, a poorly draining soil, the results show a difference of only $2 \mathrm{~kg} \mathrm{~N} \mathrm{ha}^{-1}$ between the two levels of manure.

When all the soils are considered together, the metamodel suggest that the contribution of the gaseous losses at the lower level of fertili- 

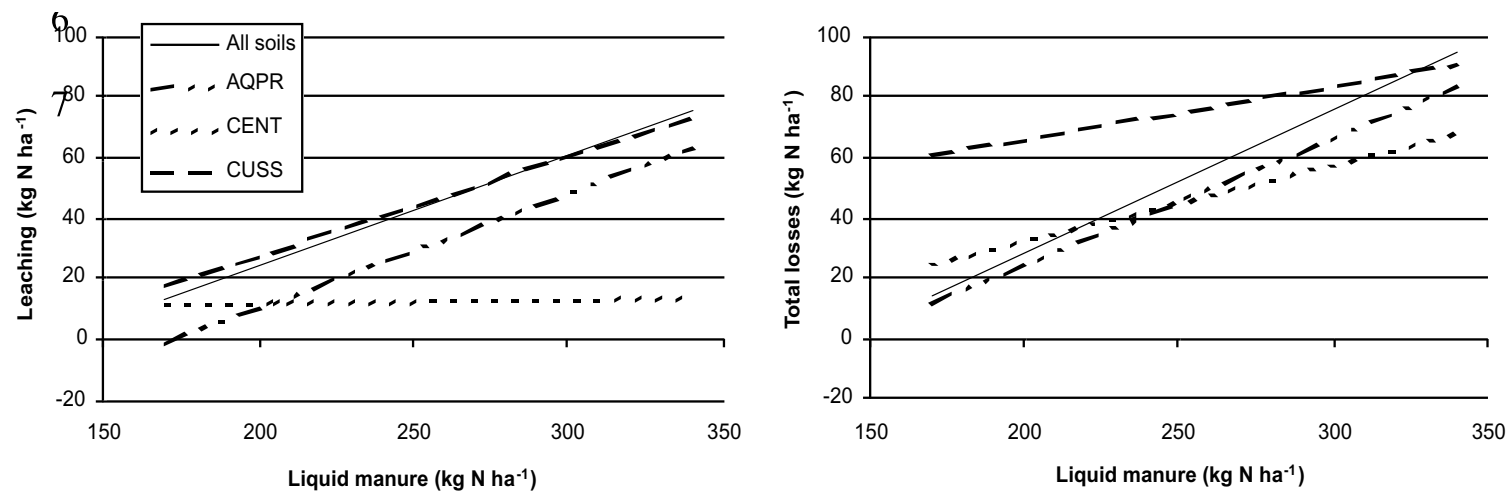

Figure 10. Example of the application of the metamodel to a maize crop fertilised with increasing levels of liquid manure. The metamodel input is fixed for solid manure $\left(0 \mathrm{~kg} \mathrm{~N} \mathrm{ha}^{-1}\right)$, potential drainage $(375 \mathrm{~mm})$, mineral fertilisation $(100 \mathrm{~kg} \mathrm{~N}$ $\left.\mathrm{ha}^{-1}\right)$ and water table ( $3 \mathrm{~m}$ deep). a) Results refer to $\mathrm{N}$ leaching; b) Results refer to total $\mathrm{N}$ losses.

sation, is almost negligible, and $\mathrm{N}$ is only lost through leaching. At the higher level of fertilisation, instead, gaseous losses can reach about 20 $\mathrm{kg} \mathrm{N} \mathrm{ha-1}$. However, there are important differences between soils. The results for AQPR are similar to those of all the soils. The effect of the increase in manure supply in CENT shows a large effect on the gaseous $\mathrm{N}$ losses and on the total $\mathrm{N}$ losses. Finally, gaseous N losses in CUSS decrease from the lower level of fertilisation to the higher level of fertilisation, showing the effect of competition between the two types of losses.

\section{Conclusions}

This work reports an application of a simulation model to predict $\mathrm{N}$ losses from a territory where most of the information is derived from a GIS built to account for the nutrient balance.

Despite the fact that the data available in the GIS were very detailed, a great deal of information necessary to run the model was lacking. Further, soil measurements concerning soil hydrology, soil nitrate content and water table depth were very valuable to produce reliable model inputs.

The results showed that even over a small area, the soils influence both the quantity and the pathways of the $\mathrm{N}$ losses to a great extent.

The ratio between the $\mathrm{N}$ losses and the $\mathrm{N}$ supplied varied between 20 and $38 \%$.

As expected, $\mathrm{N}$ gaseous losses and $\mathrm{N}$ leaching were in competition and prevailed in poorly draining or in fast draining soil, respectively.

The water table depth was important to de- termine $\mathrm{N}$ efficiency. Where it is particularly shallow, total $\mathrm{N}$ losses increase and $\mathrm{N}$ is lost through leaching or denitrification.

Metamodels were derived separately for the different crops and then both considering all the soils together or separately.

The drainage of the soil was the most important variable that influenced the water content and, as a consequence, the $\mathrm{N}$ losses. However, single soil properties, such as the average hydraulic conductivity, stone content or bulk density in the profile, were not able to predict the $\mathrm{N}$ losses from the soil.

The differences among crops were very important: it was not possible to produce any indicator to predict $\mathrm{N}$ losses when the crops are considered all together.

Estimations of total losses calculated using the metamodel are more reliable than estimations that only consider leaching. Estimations of total $\mathrm{N}$ losses from maize or meadows are more reliable than from winter cereals.

Manure input always played the highest role in determining the $\mathrm{N}$ losses. In draining soils, other important factors were mineral fertilisation and potential drainage, which instead played a minor role in poorly draining soils.

Only a synthesis of the results obtained over the area is reported in this paper. However the combined application of the GIS and the simulation model makes it possible to connect the model predictions and the spatial-temporal georeferenced input data (Rao et al., 2000). This tool is therefore able to show where agricultural activities produce the most severe environ- 
mental impacts (Gardi, 2001) and specific suggestions on agricultural practices could be given to farmers in relation, for example, to the different soil types or different water table depths.

\section{Acknowledgements}

This project was funded by Regione Piemonte, Assessorato Ambiente, parchi e aree protette, risorse idriche, acque minerali e termali, energia and Assessorato Agricoltura, tutela della fauna e della flora.

\section{References}

Aarts H.F.M., Habekotté B., van Keulen H. 2000. Nitrogen management in the "De Marke" dairy farming system. Nutrient Cycling in Agroecosystems, 56:231-240.

Arcara P.G., Gamba C., Bidini D., Marchetti R. 1999. The effect of urea and pig slurry fertilization on denitrification, direct nitrous oxide emission, volatile fatty acids, water-soluble carbon and anthrone-reactive carbon in maize-cropped soil from the Po plain (Modena, Italy). Biology and Fertility of Soils, 29:270-276.

Bechini L., Bocchi S., Maggiore T. 2003. Spatial interpolation of soil physical properties for irrigation planning. A simulation study in Northern Italy. European Journal of Agronomy, 1:1-14.

Donatelli M., Stöckle C.O., Ceotto E., Rinaldi M. 1997. Evaluation of CropSyst for cropping system at two location of northern and southern Italy. European Journal of Agronomy, 6:35-45.

ERSAL 1992. Piano di utilizzazione agronomica dei liquami e di altre deiezioni zootecniche. Ente Regionale di Sviluppo Agricolo della Lombardia, Milano, $61 \mathrm{pp}$.

EEC 1991. Council Directive 91/676/EEC of 12 December 1991 concerning the protection of waters against pollution caused by nitrates from agricultural sources. Official Journal, L 375:1-8.

EEC 1999. Council Regulation (EC) No 1257/1999 of 17 May 1999 on support for rural development from the European Agricultural Guidance and Guarantee Fund (EAGGF) and amending and repealing certain Regulations, L 160, 80-102.

Eltun R., Korsæth A., Nordheim O. 2002. A comparison of environmental, soil fertility, yield, and economical effects in six cropping systems based on an 8-year experiment in Norway. Agriculture, Ecosystems and Environment, 90:155-168.

Gardi C. 2001. Land use, agronomic management and water quality in a small Northern Italian watershed. Agriculture, Ecosystems and Environment, 87:1-12.

Giardini, L., 2004. Productivity and sustainability of different cropping systems - 40 years of experiments in Veneto Region (Italy). Patron Editore, Bologna.
Giardini L., Giupponi C. 1993. Proposta metodologica per la determinazione della capacità ricettiva del territorio per l'impiego agronomico dei liquami zootecnici. Rivista di Agronomia, 27:149-159.

Grignani C., Bassanino M., Zavattaro L., Sacco D. 2003. Il bilancio degli elementi nutritivi per la redazione dei piani di concimazione. Rivista di Agronomia, 37:155-172.

Grignani C., Zavattaro L. 2000. A survey on actual agricultural practices and their effects on the mineral nitrogen concentration of the soil solution. European Journal of Agronomy, 12:251-268.

Hofstra N., Bouwman A.F. 2005. Denitrification in agricultural soils: summarizing published data and estimating global annual rates. Nutrient Cycling in Agroecosystems, 72:267-278.

IPLA. 2006. Carta dei suoli 1:50.000. Regione Piemonte, http://www.regione.piemonte.it/agri/suoli_terreni/suol i1_50/carta_suoli.htm.

Italy 2006. D.lgs. n. 152 del 3 aprile 2006. Norme in materia ambientale. GU n. 88 del 14/04/2006 - Supplemento ordinario n. 96.

Karlsson L.O.T., Andrèn O., Katterer T., Mattsson L. 2003. Management effects on topsoil carbon and nitrogen in Swedish long-term field experiments - budget calculations with and without humus pool dynamics. European Journal of Agronomy, 20:137-147.

Marchetti R., Donatelli M., Spallacci P. 1997. Testing Denitrification Functions of Dynamic Crop Models. Journal of Environmental Quality, 26:394-401.

Monaco S. 2006. Effect of rotation and fertilisation managements in maize cropping systems. $\mathrm{Ph}$. D. Thesis. $114 \mathrm{pp}$.

Monaco S., Sacco D., Grignani C. 2002. Analysis of the influence of different environmental factors on crop growth. In: Proceedings "VII Congress of the European Society for Agronomy", 15-18 July, Cordoba, Spain, 303-304.

Morari F., Giupponi C. 1997. Effects of four cultivation systems for maize on nitrogen leaching 2. Model simulation. European journal of Agronomy, 6:113-123.

Morari F., Lugato E., Borin M. 2004. An integrated nonpoint source model-GIS system for selecting criteria of best management practices in the Po Valley, North Italy. Agriculture, Ecosystems and Environment, 102:247-262.

Nevens F., Reheul D. 2005. Agronomical and environmental evaluation of a long-term experiment with cattle slurry and supplemental inorganic N applications in silage maize. European Journal of Agronomy, 22:349-361.

Öborn A.C., Edwards E., Witter E., Oenema O., Ivarsson K., Withers P.J.A., Nilsson S.I., Richert Stinzing A. 2003. Element balances as a tool for sustainable nutrient management: a critical appraisal of their merits and limitations within an agronomic and environmental context. European Journal of Agronomy, 20:211-225. 
Padovani L., Trevisan M. 2002. I nitrati di origine agricola nelle acque sotterranee. Quaderni di Tecniche di Protezione Ambientale, Sezione Protezione delle acque sotterranee. Pitagora Ed. Bologna, vol. 75, 103 pp.

Rao M.N., Waits D.A., Neilsen M.L. 2000. A GIS-based modelling approach for implementation of sustainable farm management practices. Environmental Modelling and Software, 15:745-753.

Regione Emilia Romagna 1993. Manuale per la gestione e l'utilizzazione agronomica dei reflui zootecnici. Centro Ricerche Produzioni Animali, 317 pp.

Regione Piemonte 2002. DPGR n. 9/R del 18/10/2002. Regolamento regionale recante: Designazione delle zone vulnerabili da nitrati di origine agricola e relativo programma d'azione. BU 24 ottobre 2002, n. 43 - Suppl. ord. n. 2.

Sacco D. 2000. Vulnerabilità ambientale di un territorio ad indirizzo produttivo foraggero-zootecnico. Uso integrato delle informazioni disponibili a diversa scala per la stima della lisciviazione dell'azoto. $\mathrm{Ph}$. D. Thesis, 165 pp.

Sacco D., Bassanino M., Grignani C. 2003a. Developing a regional agronomic information system for estimating nutrient balances at a larger scale. European Journal of Agronomy, 20:199-210.

Sacco D., Monaco S., Zavattaro L., Grignani C. 2003 b. The sustainability of low input systems in comparison to traditional system for herbaceous crops. In:
Proceedings of "XXX CIOSTA-CIGR CONGRESS”, 22-24 September, Turin, Italy, 549-556.

Sacco D., Stöckle C.O., Zavattaro L. 2001. Modelling water balance in shallow watertable areas. In: Proceedings " 2 nd International Symposium Modelling Cropping Systems", 16-18 July, Florence, Italy, 85-86.

Schröder J.J., Aarts H.F.M., ten Berge H.F.M., van Keulen H., Neeteson J.J. 2003. An evaluation of whole-farm nitrogen balances and related indices for efficient nitrogen use. European Journal of Agronomy, 20:33-44.

Sommer S.G., Hutchings N.J. 2001. Review: Ammonia emission from field applied manure and its reduction - invited paper. European Journal of Agronomy, 15:1-15.

Stöckle C.O., Donatelli M., Nelson R. 2003. CropSyst, a cropping systems simulation model. European Journal of Agronomy, 18:289-307.

Thomsen I.K. 2005. Crop N utilization and leaching losses as affected by time and method of application of farmyard manure. European Journal of Agronomy, 22:1-9.

USDA 1977. Keys to Soil Taxonomy. Soil Survey Staff, Soil Conservation Service US. Dept. of Agriculture, $7^{\text {th }}$ edition, Pocahontas Press, Inc., Virginia, Usa, 545 pp.

Webb J., Harrison R., Ellis S. 2000. Nitrogen fluxes in three arable soils in theUK. European Journal of Agronomy, 13:207-223. 